\title{
Introduction Intersubjectivity, Desire, and Mimetic Theory: René Girard and Psychoanalysis
}

Link to publication record in Manchester Research Explorer

\section{Citation for published version (APA):}

Diazzi, A., \& Antonello, P. (2019). Introduction Intersubjectivity, Desire, and Mimetic Theory: René Girard and Psychoanalysis. Contagion: Journal of Violence, Mimesis, and Culture, 26, 1-8.

\section{Published in:}

Contagion: Journal of Violence, Mimesis, and Culture

\section{Citing this paper}

Please note that where the full-text provided on Manchester Research Explorer is the Author Accepted Manuscript or Proof version this may differ from the final Published version. If citing, it is advised that you check and use the publisher's definitive version.

\section{General rights}

Copyright and moral rights for the publications made accessible in the Research Explorer are retained by the authors and/or other copyright owners and it is a condition of accessing publications that users recognise and abide by the legal requirements associated with these rights.

\section{Takedown policy}

If you believe that this document breaches copyright please refer to the University of Manchester's Takedown Procedures [http://man.ac.uk/04Y6Bo] or contact uml.scholarlycommunications@manchester.ac.uk providing relevant details, so we can investigate your claim.

\section{OPEN ACCESS}




\title{
Introduction
}

\section{Intersubjectivity, Desire, and Mimetic Theory: René Girard and Psychoanalysis}

\author{
Pierpaolo Antonello \\ University of Cambridge
}

Alessandra Diazzi

University of Manchester

he aim of this special collection of essays, titled Intersubjectivity, Desire, and Mimetic Theory: René Girard and Psychoanalysis, is to reappraise the 1 relationship between René Girard's thought and the psychoanalytic tradition. The tripartite structure of the title clearly echoes the English title of Girard's first book, Deceit, Desire and the Novel, with which he introduced the psychological dynamics of mimetic desire as represented in modern European novels. " Through the reference to the intentionally broad notions of "intersubjectivity," "desire," and "mimetic theory," our title also signals the intention to cover the multifarious aspects and issues that inform Girard's thinking in relation to core issues of psychoanalysis, by casting the net very broadly and exploring the theoretical implications of the encounter between the mimetic and the psychoanalytic discourse in a variety of fields and disciplines, such as philosophy, literary criticism, anthropology, psychotherapy, neuropsychology, and socio-psychology. On the one hand, this collection discusses the potential theoretical and discursive integrations that mimetic theory would need in order to account for various psychological manifestations, including psychopathologies of different kinds, and social phenomena; on the other hand, the collection 
brings to light contentious issues within the psychoanalytic literature that a mimetic approach to individual psyche and collective behavior might contribute to illuminating.

The critical literature in the field of psychology and psychoanalysis increasingly seems to recognize the intersubjective makeup of our psyche, which is in fact, as Girard stated more than 50 years ago, preverbal and dialogic. This view was recently substantiated from a neurocognitive standpoint through the discovery of the mirroring mechanism that lies at the base of our capacity for learning, and empathic attunement with others. ${ }^{2}$ In spite of this evident kinship between mimetic theory and psychological/psychoanalytic findings on psyche, scholarship has almost completely ignored the contribution made by Girard and Girardians to the discussion. As a result, Girard's reassessment of psychoanalysis has only had marginal traction outside of Girardian criticism.

The reason for this oversight is most likely to be found in Girard's own attitude toward psychoanalysis. With the exception of the pages of sharp criticism dedicated to a set of Freudian theories, Girard has never fully engaged with psychoanalysis. The reassessment of Freud is mostly confined to a few chapters of Violence and the Sacred and Things Hidden since the Foundation of the World. ${ }^{3}$ This also resulted in a cursory dismissal of figures such as Jacques Lacan, Melanie Klein, and Donald Winnicott, despite the potential intersections between the work of these thinkers and Girard's oeuvre. ${ }^{4}$ This combination of criticism and indifference induced the general overlooking of possible encounters between Girardian and psychoanalytic circles that we have observed in recent decades.

There have been, however, a few valuable exceptions. Jean-Michel Oughourlian has been Girard's closest interlocutor as far as the criticism of Freud from a mimetic point of view is concerned. He made mimetic theory the core of his work as a clinician, putting forward a theory of psyche grounded on the notion of mimesis as the force driving the subject and its social relationship. The idea of a "universal mimesis" as a gravitational force that binds us all together is a powerful metaphor, but also an effective heuristic tool that can clarify many of the behavioral oscillations that are so commonly found in psychopathology, in our constant pendularism between imitation and rivalry - the latter being a concept that has not been adequately conceptualized in psychoanalysis.

Carrying further the critique of Freud's psychoanalysis elaborated with Girard, Oughourlian challenged the Freudian supremacy in the field of psychiatry and psychotherapy by questioning the notion of the unconscious. In The Puppet of Desire (1982), he claims that "the Freudian unconscious, that mythic hypostasis peopled with all sorts of occult mythic forces in conflict with one

This work originally appeared in Contagion 26, 2019, published by Michigan State University Press. 
another, ... simply does not exist."' This must be replaced with the idea of "the other"-that is to say, the model-as the concealed force shaping the subject's desires and behavior. ${ }^{7}$

Eugene Webb, in his work The Self Between: From Freud to the New Social Psychology of France (1993), also called for a Girardian reassessment of psychological research. He acknowledges that the most essential discovery of Girard is the fundamental influence of the dynamics of imitation on individual and collective psychology. ${ }^{8}$ In particular, Webb emphasizes the shift that the Girardian approach to psychology and psychoanalysis implies, "from a fundamentally idealistic approach to understanding human psychology through language and abstract logic ... to an approach that emphasizes the concrete actuality of human relations in ordinary life and history." After outlining the genesis of the "psychology of mimetic desire," Webb concludes that "psychological mimesis" must be recognized as a foundational process in human behavior, which deserves "a careful hearing" on the part of psychoanalysis and psychology. ${ }^{10}$ Webb's further contribution to the dialogue between mimetic theory and psychoanalysis is the analysis of the common Hegelian matrix of Girard and Lacan, particularly through the mediation of Alexandre Kojève, ${ }^{11}$ which led him to also engage a dialogue with Mikkel Borch-Jacobsen's work Lacan: the Absolute Master (1991).

A further fundamental contribution to the dialogue between mimetic theory and psychoanalytic theories comes from Martha Reineke, who is credited with having brought a much-needed reflection on gender and femininity into the Girardian hermeneutics. In Sacrificed Lives: Kristeva on Women and Violence (1997), she proposed a theory of sacrifice that put Girard in dialogue with Kristeva in order to understand female sacrifice and the rise of violence in gender conflicts. Reineke has furthermore identified Girardian echoes in Winnicott's object relations theory and theory of aggression, revealing the extent to which mimetic theory intersects analytical discourses beyond Freudianism. ${ }^{12}$

A further crucial playing field between psychoanalysis and mimetic theory is neuropsychology, which in recent years has put to the test-confirming and challenging - both Freudian and Girardian hypotheses. It is Scott Garrels who, along with Jean-Michel Oughourlian, brought together theorists of imitation and intersubjectivity, such as Andrew Meltzoff and Vittorio Gallese, to discuss and provide a first assessment of Girard's theory from a neuroscientific point of view. ${ }^{13}$ As the extensive theoretical literature produced in the last decade testifies, the discovery of mirror neurons has been reshaping current discourses and approaches to issues such as subjectivity, intentionality, empathy, self-awareness, language, theory of mind, and so on, and has inflected the theoretical discussion in a variety of fields, from psychology to anthropology

This work originally appeared in Contagion 26, 2019, published by Michigan State University Press. 
and philosophy. However, in respect to mimetic theory, there are numerous issues and problems that require a more systematic assessment. In spite of the fact that mimetic desire has been conceptualized as prelinguistic and preconscious, there has been a lack of discussion, for instance, of the role of mimetic desire in infancy, and the articulation of experiences of bonding, attachment, and intimacy, and the coordination of inner and relational states. From the point of view of psychoanalysis, there have been some initial speculative considerations of the theoretical and practical implications of the discovery of mirror neurons, particularly in relation to issues such as empathic attunement, projective identification, and countertransference. On this score, Ruth Leys, taking into account Girard's position, has provided thoughtful considerations on the role of mimesis in behavioral sciences, particularly in the articulation of the notion of trauma, and on the "post-psychoanalytic turn" as a consequence of the emergence of the new neurocognitive paradigm. ${ }^{14}$

The contributions to this volume are situated on the path that these fundamental precedents tread, with the aim of extending the reassessment of both tensions and negotiations characterizing the encounters between psychoanalysis and mimetic theory. To this end, the issue gathers contributions that explore three different-but closely interwoven-areas of inquiry: the clinical field (Garrels and Bustrum; Frost); literature, culture, and philosophy (Reineke; Diazzi; Lawtoo); and socio-politics (Janicka; Brighi). In reference to the first one, Scott R. Garrels and Joy M. Bustrum discuss the potential convergence between contemporary North American psychoanalysis and interdividual psychology, showing that-despite the encounter between mimetic theory and psychoanalysis mostly being missing - the two have a potential and fruitful applicability in clinical practice. After providing an overview of the current psychoanalytic trends that resonate most with Girard's ideas, the authors embed mimetic insights into the examination of a clinical case taken from Jody Davies's article "Whose Bad Objects Are We Anyway?" which deals with shame-riddled bad self-representations in both patient and analyst. The exchange between the mimetic and analytical poles in the practice of clinics is also investigated by Kathryn M. Frost, who put into dialogue Girard's mimetic theory with a developmental approach to the psyche, by making use of attachment theory.

Moving from the clinical to the cultural field, Martha J. Reineke explores the possible consonance of psychanalysis and mimetic theory by returning to Girard's earliest source for the development of his theory of mimetic desire, the novel. In fact, Reineke takes as her point of departure Girard's reading of Don Quijote, drawing on the psychoanalysis of trauma to expand and problematize the interpretation of the novel given in Deceit, Desire and the Novel. A historical

This work originally appeared in Contagion 26, 2019, published by Michigan State University Press. 
and cultural perspective also informs Alessandra Diazzi's contribution, which discusses the work of one of the most original Italian psychoanalysts, Elvio Fachinelli, from the point of view of a mimetic understanding of his practice and writing. Specifically, she identifies a cluster of "mimetic questions" shaping Fachinelli's analysis of the intrinsic violence characterizing the Italian 1968 student protest and political groups. The key issue of violence is also central to Nidesh Lawtoo's contribution, which articulates the genealogical (dis)continuities between René Girard's anthropological theory of violence and Sigmund Freud's early theory of the unconscious, by focusing on the Aristotelian concepts of katharsis and mimesis that arguably shape both theories.

The third focal point of this volume further expands toward sociopsychological analysis the theoretical reach of a psychoanalytically inflected mimetic theory looking at fundamental political implications. Iwona Janicka explores Rancière's idea that nineteenth-century workers' impulse for emancipatory political action did not come from enduring hunger, low wages, and poverty alone, but rather from learning a new bourgeois form of experience through reading a certain type of literature. Taking this hypothesis as her starting point, Janicka interrogates this new form of "mimetic suffering" from Girard's mimetic perspective, examining a form of political awareness and subjectification that can be developed within a mimetic framework.

Elisabetta Brighi then moves closer to contemporary issues, by discussing the rise of terrorism fueled by global resentment against the background of the multiplication and denial of failure in world politics. In particular, her article examines the place of resentment and ressentiment in the affective and moral economy of the global age, teasing out the key distinctions between the two emotions and the political relevance of this differentiation.

In conclusion, considering the complexity and potential theoretical ramifications of the matters that our contributors address, this collection aims to pave the way for future studies on mimetic theory and psychoanalysis hereby explored, rather than to advance a definitive view of their encounter. Our hope is, first, to bring to light new points of commonality between the two discourses under scrutiny, and second, to show the variety of fields that may benefit from an integrated perspective, combining the mimetic framework with a psychoanalytic approach. We would therefore like this collection to be considered as a starting point for a closer theoretical and practical engagement between psychoanalysis and Girard's thought, which may contribute to a "rapport" of full and mutual recognition. 


\section{NOTES}

This special collection was inspired by the conference Intersubjectivity, Desire, and the Mimetic Brain: René Girard and Psychoanalysis, co-organized by Pierpaolo Antonello, Alessandra Diazzi, and Scott Garrels, and held at St John's College, University of Cambridge, November 11-12, 2016. We acknowledge the generous contribution of the Faculty of Modern and Medieval Languages, and St John's College, Cambridge.

1. René Girard, Deceit, Desire and the Novel (Baltimore: Johns Hopkins University Press, 1965).

2. See Vittorio Gallese and Maxim I. Stemenov, eds., Mirror Neurons and the Evolution of Brain and Language (Amsterdam and Philadelphia: John Benjamins Publishing Company, 2002); Pier Francesco Ferrari and Giacomo Rizzolatti, eds., New Frontiers in Mirror Neurons Research (Oxford: Oxford University Press, 2015); Ruth Leys, The Ascent of Affect: Genealogy and Critique (Chicago: Chicago University Press, 2017).

3. See René Girard, "Totem and Taboo and the Incest Prohibition," in Violence and the Sacred (Baltimore: Johns Hopkins University Press, 1979), 193-222, and "Interdividual Psychology," in Things Hidden since the Foundation of the World: Research Undertaken in Collaboration with Jean-Michel Oughourlian and Guy Lefort (Stanford, CA: Stanford University Press, 1987), 352-92. For a detailed recognition of Girard's criticism of Freud, see Girard, "The Challenge to Freud and Nietzsche," in The Girard Reader, ed. James G. Williams (New York: The Crossroad Publishing Company, 1996), 223-42.

4. Maurizio Meloni, “A Triangle of Thought: Girard, Freud, Lacan," Journal of European Psychoanalysis 14 (2002): 27-56.

5. On the notion of "interdividual psychology" Jean-Michel Oughourlian states: "In 1978, in Things Hidden since the Foundation of the World, René Girard, Guy Lefort, and I forged the expression 'interdividual psychology' to express our conviction that the monadic subject doesn't exist, that the self is formed only in relations with the other, and that psychology cannot focus on individuals but only on rapports and relationships." Jean-Michel Oughourlian, The Mimetic Brain (East Lansing: Michigan State University Press, 2016), 33 .

6. Jean-Michel Oughourlian, The Puppet of Desire: The Psychology of Hysteria, Possession, and Hypnosis (Stanford, CA: Stanford University Press, 1991), 152.

7. In the same volume, Oughourlian also investigated trance and hysteria through the lenses of mimesis and imitation, thereby breaking with the Freudian understanding of the same phenomena.

8. Eugene Webb has also explored possible resonances between René Girard and Carl Gustav Jung in "Eros and the Psychology of World Views," in Kulturen des Eros, ed. Detlev Clemens and Tilo Schabert (Munich: Wilhelm Fink Verlag, 2001), 179-230.

9. Eugene Webb, The Self Between: From Freud to the New Social Psychology of France (Seattle: University of Washington Press, 1993), 88.

10. Webb, The Self Between, 213.

11. Webb, The Self Between, 116.

12. Martha J. Reineke, Sacrificed Lives: Kristeva on Women and Violence (Bloomington: Indiana University Press, 1997); Reineke, "Sacrifice and Sexual Difference: Insights and 
Challenges in the Work of René Girard," in For René Girard: Essays in Friendship and in Truth, ed. Sandor Goodhart, Jørgen Jørgensen, Tom Ryba, and James G. Williams (East Lansing: Michigan State University Press, 2009), 247-58; Reineke, “Transforming Space: Creativity, Destruction, and Mimesis in Winnicott and Girard," in Contagion: Journal of Violence, Mimesis, and Culture, vol. 14 (2007): 79-95.

13. Scott Garrels, ed., Mimesis and Science: Empirical Research on Imitation and the Mimetic Theory of Culture and Religion (East Lansing: Michigan State University Press, 2011).

14. See Ruth Leys, Trauma: A Genealogy (Chicago: University of Chicago Press, 200o), and Leys, The Ascent of Affect: Genealogy and Critique (Chicago: University of Chicago Press, 2017).

PIERPAOLO ANTONELLO is Reader in Italian literature and culture at the University of Cambridge (UK) and Fellow of St John's College. With René Girard and João Cezar de Castro Rocha he published Evolution and Conversion: Dialogues on the Origins of Culture (London: Continuum, 2007). He also edited several collections of essays on mimetic theory, including How We Became Human: Mimetic Theory and the Science of Evolutionary Origins, with Paul Gifford (East Lansing: Michigan State UP, 2015), and Mimesis, Desire, and the Novel (East Lansing: Michigan State UP, 2015), with Heather Webb. He is member of the advisory board of "Imitatio: Integrating the Human Sciences."

ALESSANDRA DIAZZI studied modern literary studies at the University of Milan where she graduated in 2008 (BA) and in 2010 (MA). In 2015 she was awarded with a $\mathrm{PhD}$ in Italian Studies at the University of Cambridge discussing a thesis on the reception of psychoanalysis in post-WWII Italian literature and culture. Alessandra published on contemporary Italian writers (Calvino, Moravia, Ottieri), Italian cinema and the terrorism, and on the uses of the notion of desire in literary criticism. She is currently lecturer in Italian Studies at the University of Manchester.

This work originally appeared in Contagion 26, 2019, published by Michigan State University Press. 
This work originally appeared in Contagion 26, 2019, published by Michigan State University Press. 